Egypt. Poult. Sci. Vol. (41) (III): (489-505)(2021)

Egyptian Poultry Science Journal

http://www.epsj.journals.ekb.eg/

ISSN: 1110-5623 (Print) - 2090-0570 (Online)

\title{
DIRECT AND MATERNAL GENETICS WITH ENVIRONMEYTA' EFFECT FOR EGG QUALITY AND HATCHABILITY OF GIMMIZAH CHICKENS SELECTED FOR BODY WEIGHT
}

\author{
N.G. Boutrous; and R. E. Rizk \\ Anim. Prod. Res. Inst., Agric. Res. Cent, Egypt

Received: 29/06/2021 Accepted: 29/08/2021

Corresponding author: Nabile G. Boutrous, Email: Nabiiiiiiile.s.b@gmail.com

\begin{abstract}
The present experiment was conducted on Gimmizah (GM) chickens selected for body weight at 12 -wk of age through three generations aiming for detection the genetic components of direct, maternal and environmental effects of egg quality traits and hatchability. Second generation of GM chickens selected for body weight represent increase $(p>0.05)$ of some egg quality traits such as hatching egg weight, egg shape index, egg surface area, egg shell density, eggshell thickness without membranes, albumen weight, albumen height, yolk weight, and egg shell weight compared with those for base population $\left(\mathrm{G}_{0}\right)$ and first generation $\left(\mathrm{G}_{1}\right)$. Generally, Additive genetic maternal was surpassed those for the additive genetic direct and permanent environmental hen effects for the most studied traits. Realized heritability estimates among the three selected generations proved that the records of direct estimate $\left(\mathrm{h}^{2}{ }_{\mathrm{a}}\right)$ had highest value of heritability compared with those for maternal $\left(\mathrm{h}_{\mathrm{m}}^{2}\right)$ and permanent environmental hen effect $\left(\mathrm{h}_{\mathrm{pe}}^{2}\right)$ with respect to hens body weigh at 45 -wk of age, hatching egg weight, egg surface area, eggshell thickness without membranes, albumen weight, albumen height, yolk weight ratio, eggshell weight, eggshell weight percent, albumen weight percent, and yolk/albumen ratio. Also, highly significant positive genetic correlations are detected between most of the studied egg quality traits and hatchability. Also, there are highly maternal positive maternal genetic correlations between hatching egg weight and each of egg shape index, eggshell thickness, albumen weight, albumen height, yolk weight, fertility, total embryonic mortality and hatchability of fertile eggs.

The obtained results of low estimates of heritability for fertility and hatchability and the highly estimates for egg quality traits besides the highly direct and maternal genetic correlations suggesting the applicability of some egg quality traits in programming the selection index combining with body weight selection as indirect way for improving fertility and hatchability with body weight.
\end{abstract}

Keywords: Genetic; Hatchability; Egg Quality; Heritability 


\section{INTRODUCTION}

There have been very few published papers on the estimation of genetic parameters for production and reproduction traits using different animal models in native chickens (Emamgholi Begli et al., 2010). Ghorbani et al. (2012) estimated the genetic parameters involved of production and reproduction traits of the native fowl is an important aspect of planning breeding schemes. Indigenous chickens have great potential for genetic improvement and it is vitally important to consider maternal effects in genetic evaluation of native breeds (Liu et al., 2011). Maternal effects are defined as any influence of a dam on the phenotype of her off springs in addition to her direct transmitted genes (Willham, 1980). Two commonly modelled maternal effects for body weight traits are additive genetic and permanent environmental effects of the dam (Barbieri et al., 2015).

Several papers about selection on body weight have reported positive correlated effects on egg weight and analyzed egg quality traits (Marks, 1979). Egg quality is affected by selection on body weight, but these effect differ between experiments may be in relation to their origin breeding lines (Minvielle and Oguz, 2002). The most comprehensive genetic analysis of egg quality was carried out by Stino et al. (1982) who obtained values from sire and dam components. Also, Salehinasab et al. (2014) confirmed that egg quality traits are a major selection criterion in poultry breeding and they found that body weight of partridges significantly affected egg weight, yolk weight, specific gravity, shell weight, shell thickness, and albumen weight.

Wolc and Olori (2009) mentioned that sire and dame genetic components are important in hatchability because of the significant effect of these components on fertility and embryonic mortality. Siegel and Dunnington (1985) demonstrated that body weight is generally considered as having moderate heritability and used in experiments designed to examine both direct and correlated genetic changes in populations undergoing artificial selection. Also, Saatci et al. (2006) found strong correlation between direct genetic effect of egg traits and maternal genetic effect of body weight. The maternal effect influenced the progeny phenotype due to genetic and environmental differences between dams (Grosso et al., 2010).

Purpose of this study was to more clearly define and understand the genetic impact of direct and maternal genetics besides environmental effect component of egg quality and hatchability traits through consequent three generations of body selection for Gimmizah chickens.

\section{MATERIALS AND METHODS}

The present experiment was conducted on Gimmizah (GM) chicken strain at EL-Sabahia Poultry Research Station, Agriculture Research Center. One hundred and twenty GM hens besides twelve males grown on litter were randomly chosen from the flock and considered as base $\left(\mathrm{G}_{0}\right)$ population composing pen s families. Day-old chicks produced from the base population were wing-banded and selected for body weight at 12-wk of age as equal or graters than average of the flock. After twenty weeks of age, males and female were transferred into the single cage composing the first generation $\left(\mathrm{G}_{1}\right)$ (n:298). The hens were artificially inseminated by a single cock for composing the families. The 
Genetic; Hatchability; Egg Quality; Heritability

chicks produced from the selected parents of $G_{1}$ were selected for body weight at 12wk of age and transferred to the cages and considered as second generation $\left(\mathrm{G}_{2}\right)$ (n:198) A total number of 3220 hatching GM eggs produced from chickens aged between $45-50 \mathrm{wk}$ and representing the three experimental consecutive generations (1057, 1282 and 881 eggs, respectively) were used for hatching trials. Eggs were individually numbered and marked by dams and sires for each generation then they were weighed prior the beginning of incubation in Egyptianmade incubator at $99.5 \mathrm{~F}^{\circ}$ and $55 \%$ relative humidity $(\mathrm{RH})$ during setting phase and $98.60 \mathrm{~F}$ with $65 \% \mathrm{RH}$ during hatching phase. Eggs were randomly distributed in trays as replicate in the incubator.

Eggs that failed to hatch and having full opportunity to hatch were broken out then examined macroscopically to estimate total embryonic mortality. Embryonic mortality percentage expressed as a percentage of fertile eggs set was recorded. Macroscopic fertility and hatchability of fertile egg percentages were detected. Chicks that had fully emerged from eggs were wing banded and weighed to the nearest $0.1 \mathrm{~g}$ and recorded as hatched chick weight pedigreed for hens. Also, hatched chick weight was expressed as percentage relative to egg weight.

Egg quality traits were determined on 350 hatching eggs representing all studied families through all experimental generations from hens aged 45-50 weeks. The studied traits were egg albumen weight(g), yolk and shell weights(g), egg shape index as the percentage of egg width on egg length, shell without membranes thickness ( $\mathrm{mm})$, albumen height $(\mathrm{mm})$ with micrometer. Egg surface area $\left(\mathrm{cm}^{2}\right)$ was calculated as the formula of Carter (1975); Eggshell density $\left(\mathrm{g} / \mathrm{cm}^{2}\right)$ was calculated by the formula of Curtis et al. (1985), Yolk weight \%, albumen weight $\%$, eggshell weight $\%$, and yolk/albumen ratio were detected.

Statistical Methods

In the analyses by the animal model, the animals which did not have any relation with the others, or those which did not contribute to the information collected and had any link were excluded from the genetic relationship matrix through a process of pruning, performed in a first phase through software Wombat (Meyer, 2007). In this process individuals that are sire or dam and which do not contribute to the information for variance component estimation, i.e. individuals without records and a pedigree link to at least one other individual, are replaced with an "unknown" code and eliminated from the list of the pedigree records (Meyer, 2010).

Afterwards, single-trait analysis was carried out; for body weights, only fixed effects of sex and of generation/ hatch were considered, and for productive traits of female breeders, only fixed effects of generation/hatch. These estimates served to build up the genetic used as initial values for estimation of variance components in a multi - trait analysis.

For all genetic analyses, the package Wombat was used, (Meyer, 2007) with standard algorithms of the system. The model can be represented in matrix terms by

$$
\mathrm{y}=\mathrm{Xb}+\mathrm{Za}+\mathrm{e}
$$

where $y$ is the vector of observations; $\mathrm{X}$ is the incidence matrix of fixed effects; $b$ is the vector of fixed effects; $Z$ is the incidence matrix of random effects; $a$ is the vector of 
random effects; $\mathrm{e}$ is the vector of residuals.

The model used is:

$\mathrm{y}=\mathrm{Xb}+\mathrm{Za}+\mathrm{Wm}+\mathrm{e}$

where $\mathrm{m}$ is a vector of random maternal additive genetic effects; $\mathrm{W}$ is the incidence matrix for these maternal effects; $\mathrm{y}, \mathrm{b}, \mathrm{a}, \mathrm{e}, \mathrm{X}$ and $\mathrm{Z}$ - are as above.

The following genetic parameters were estimated: direct heritability $\left(\mathrm{h}_{\mathrm{a}}^{2}=\sigma_{\mathrm{a}}^{2} / \sigma_{\mathrm{p}}^{2}\right)$, maternal heritability $\left(h_{m}^{2}=\sigma_{\mathrm{m}}^{2} / \sigma_{\mathrm{p}}^{2}\right)$. Approximate sampling errors of the heritability estimates were calculated by fitting a quadratic function to the respective profile likelihood. where $\sigma_{\mathrm{m}}^{2}$ is the maternal additive genetic variance, $\sigma_{\mathrm{am}}$ is the covariance between direct and maternal additive effects; other symbols as above.

Where, $\sigma_{\mathrm{a}}^{2}, \sigma_{\mathrm{m}}^{2}$ and $\sigma_{\mathrm{pe}}^{2}$ are additive genetic variance, maternal genetic variance, and maternal permanent environmental, respectively.

An evaluation of the significance of maternal effects is performed using differences in logarithm of the likelihood obtained for models I and II.

Variance components, and genetic parameters were estimated using REML procedures. Starting values of population parameters used in calculating breeding values were obtained from series of univariate analyses using the REML method. These estimates served to build up the genetic and residual (co)variance matrices used as initial values for estimation of variance components in a multi-trait analysis. All analyses included pedigrees back to the base population. Phenotypic variance was calculated as $\left(\sigma^{2} P=\sigma^{2} a+\sigma^{2} m+\sigma^{2} a m+\right.$ $\sigma^{2} e$ )allowing us to estimate direct heritability $\quad\left(h^{2}=\frac{\sigma^{2} a}{\sigma^{2} P}\right) \quad$,maternal heritability as $m^{2}=\frac{\sigma^{2} m}{\sigma^{2} P}$, and total heritability $\quad$ as $h^{2}=\frac{\sigma^{2} a+0.5 \sigma^{2} m+1.5 \sigma a m}{\sigma^{2} P}$ according to Willham (1972). All other statistical analyses were performed by SAS (SAS, 2016). A coefficient was considered for each trait of interest based on an aggregate genotype model, with the higher coefficient values for reproductive traits (fertility, hatchability, etc.) in the sire line.

Genetic, phenotypic, and environmental correlations were estimated using biraviate analyses with the same fixed effects in univariate models (Yavarifard et al., 2015).

\section{RESULTS AND DISCUSSION}

Data of Table 1 represent the effect of body weight selection at 12-wk of age on some performance traits of Gimmizah chickens throughout three selected generations. Second generation represents significant ( $p>0.05$ ) increase of each for some egg quality traits such as hatching egg weight, egg shape index, egg surface area, eggshell density, eggshell thickness without membranes, albumen weight, albumen height, yolk weight, and eggshell weight compared with those for base population $\left(\mathrm{G}_{0}\right)$ and first generation $\left(\mathrm{G}_{1}\right)$. Also, significant increases for egg shape index, egg surface area, yolk weight and yolk/albumen ratio were observed for $\mathrm{G}_{1}$ compared to those for $\mathrm{G}_{0}$. Also, data of this table represented significant improvement of fertility percentage for eggs produced through $G_{1}$ and $G_{2}$ compared with those for $\mathrm{G}_{0}$. Moreover, it is apparent from our data that embryonic mortality of the studied generations was significantly decreased for $G_{1}$ and $G_{2}$ compared with those for the base one population. The 
Genetic; Hatchability; Egg Quality; Heritability

significant decrease of embryonic mortality in $\mathrm{G}_{2}$ had been reflected on the significant increase of hatchability of fertile eggs for this generation compared to $G_{0}$ and $G_{1}$. Furthermore, $G_{2}$ represented significant increase of hatched chick body weight and hatched chick weight percentage for hens compared with those for $\mathrm{G}_{0}$ and $\mathrm{G}_{1}$.

The significant increase of hatching egg weight due to body selection in the mentioned results was previously approved by Saleh et al. (2008) and Ashour et al. (2015). Also, the significant increase of egg shape index due to body weight selection was previously documented by Younis et al. (2014) in Dokki 4 strain. While, Ashour et al. (2015) mentioned opposite results in ELSalam strain. Supporting to our results of significant increase of surface area, Yeasmin and Howlider (1998) noticed enlargement of egg surface area in dwarf strain due to body weight selection. The significant increase of egg shell thickness is confirmed by Benett (1992) who found that shell thickness ranged between 0.34 $\mathrm{mm}$ in base population to $0.44 \mathrm{~mm}$ for eggs of $2^{\text {nd }}$ generation. The results of the increase of egg albumen and yolk weights for the selected group of $G_{2}$ are in accordance with those previously reported by Amira (2018). In addition to, the increase of albumen height for egg of $\mathrm{G}_{2}$ for Gimmizah strain is previously confirmed by Salehinasab et al. (2014). The significant improvement of fertility percentage for $G_{1}$ andG $G_{2}$ due to body weight selection is in line with those reported by Saroj et al. (2020) who found that fertility percentage significantly differed according to selection as it increased by $7.7,8.3$ and $8.8 \%$ in first, second and third generations of selection, as compared to those of base population.
Regarding the embryonic mortality, Schmidt et al. (2003) found that change of mortality can be attributed to the selection for body weight. Moreover, the same auther came to the same our outcome of improving hatchability percent due body weight selection and mentioned that selection over the generations is important source of variation with respect to hatchability. Whereas, Ashour et al. (2015) reported that reproductive performance as hatchability percentage was reduced by $-0.6 \%$ after progress two generations of selection.

Results of Table 2 demonstrate that there were no apparent differences among the studied additive genetic variances with respect to hen's body weight at 45-week of age. The estimates of parental additive genetic were positively higher than those for maternal $\left(\boldsymbol{\sigma}_{\mathbf{m}}{ }\right)$ and direct $\left(\sigma^{2}{ }_{\mathrm{a}}\right)$ additive genetic variances with respect to the following traits such as egg weight, egg shape index, egg surface area, eggshell thickness, albumen weight, albumen weight percent, and yolk/albumen percent. While, $\sigma_{m}^{2}$ estimates were surpassed than those for the $\sigma_{a}^{2}$ and permanent environmental hen effects $\left(\sigma_{\text {pe }}^{2}\right)$ for hatching egg weight, egg shape index, egg surface area, eggshell thickness, albumen weight, albumen weight percent and yolk/albumen.

The indicated results of egg quality are the most important traits as they influence hatching performance. Therefore, the studied estimates of additive genetic are required in obtaining genetic gains by selection. The results of additive genetic effects in this study regarding the hatched chick weight are nearly approach with the results of Tongsiri et al. (2019) who 
reported values of $\sigma_{a}^{2}(1.20) \quad \sigma_{m}^{2}(2.96)$ and $\sigma_{\text {pe }}^{2}$ (3.13). Rahman et al. (2010) stated that the direct maternal genetic effect observed for weight at six weeks of age might be a factor transferred from ages influencing. The direct additive effect for egg quality was reported by Ayman et al. (2013) who found that egg quality estimates were positive for most egg characteristics such as egg shape index (1.99), shell thickness $(2.93 \mathrm{~mm})$, yolk percentage $(4.76 \%)$, and yolk index (0.05).

Supporting to our results regarding to the positively of maternal genetic additive for egg weight and albumen weight, Iraqi et al. (2002) found that percentage of $\boldsymbol{\sigma}_{\mathbf{m}}^{\mathbf{2}}$ for those traits were positive but negative for egg shape index.

Heritability estimates $\left(\mathrm{h}^{2}\right)$ and SE of some performance traits for GM chickens selected for body weight at 12-wk of age throughout three generations are shown in Table 3. It can be observed from data of this table that direct estimate $\left(h^{2}\right)$ had highest records of heritability compared with those for maternal $\left(\mathrm{h}_{\mathrm{m}}^{2}\right)$ and permanent environmental hen effect $\left(h^{2}{ }_{p e}\right)$ with respect to hen's body weigh at 45-wk of age, hatching egg weight, egg surface area, eggshell thickness without membranes, albumen weight, albumen height, yolk weight ratio, eggshell weight, eggshell weight percent, albumen weight percent, and yolk/albumen ratio. Also, $\mathrm{h}_{\mathrm{pe}}^{2}$ recorded higher estimates of heritability compared with those for $\mathrm{h}^{2} \mathrm{~m}$ with respect to hatching egg weight, egg shape index, egg surface area, eggshell thickness, albumen weight, eggshell weight, albumen weight percent, and yolk/albumen percent but less estimates were observed for eggshell density, albumen height, yolk weight, yolk weight ratio, shell weight percent and fertility.
Moreover, equal estimates were observed between $\mathrm{h}_{\mathrm{m}}^{2}$ and $\mathrm{h}_{\mathrm{pe}}^{2}$ with respect to hen's body weight at $45 \mathrm{wk}$ of age, total embryonic mortality and hatchability of fertile eggs.

Knowledge of the heritability for the studied traits is necessary to predict the breeding values of individuals either from direct or maternal and this notion is generally keeping with those previously reported by Grosso et al. (2010).

Supporting to the current results of increasing $\mathrm{h}_{\mathrm{a}}^{2}$ comparing with $\mathrm{h}_{\mathrm{m}}^{2}$ and $\mathrm{h}^{2}$ pe for body weight at 45- wk of age, Tongsiri et al. (2019) reported that the highest $\mathrm{h}^{2}$ a was observed on body weight at 24 weeks of age, but lowest for $\mathrm{h}_{\mathrm{m}}^{2}$. Pradeepta et al. (2015) mentioned that heritability estimate from the maternal component for surface area trait was lower than estimate from direct component referring to the less importance of maternal influence and non-additive gene action for this trait. In accordance with our results in eggshell thickness, Kheirkhah et al. (2017) reported the increase of direct heritability estimates than those for maternal genetic heritability. Contradicted results with the increase of $h^{2}$ for eggshell weight and eggshell thickness compared to $\mathrm{h}_{\mathrm{m}}^{2}$ were mentioned by Sreenivas et al. (2013). Regarding to albumen height, similar results were mentioned by Zhang (2005) and Wolc et al. (2012) who reported that albumen heights were 0.51 and 0.50 , respectively for laying hens.

The highly direct heritability (h2a) for egg surface area, eggshell thickness, albumen weight, albumen height, yolk weight ratio, eggshell weight, shell weight $\%$, albumen weight $\%$ and 
Genetic; Hatchability; Egg Quality; Heritability

yolk/albumen ratio suggesting applicability of individual selection for these egg quality traits, while selection for hens should be followed with those had highly maternal heritability such as egg shape index, eggs shell density and yolk weight.

Current results of the lower heritability estimates of fertility, embryonic mortality and hatchability are in agreement with those previously reported by Wolc et al. (2010). Referring to the increase of maternal heritability for chick body weight (0.65) compared with 0.50 for direct and 0.22 for environmental heritability, Hartmann et al. (2002) confirmed these results as they reported that maternal heritability for chick weight was 0.5 , whereas the direct heritability was close to 0.07 and added that this maternal effect on chick weight possibly mediated via egg composition.

Data of Table 4 showed direct (above diagonal) and maternal (below diagonal) genetic correlations of some performance traits such as chicken body weight at 45 week of age, hatching egg weight, fertility, hatchability of fertile eggs and some traits of egg quality for Gimmizah chickens selected for body weight at 12wk of age. It can be observed from data of direct genetic correlations that there are highly positive genetic correlations between hatching egg weight and each of egg shape index (0.74), egg shell thickness (0.54), albumen weight (0.90), albumen height $(0,68)$, fertility $(0.55)$, total embryonic mortality (0.40) and hatchability of fertile egg (0.50). Moreover, between egg shape index and each of eggshell thickness (0.99) albumen weight (0.78), albumen height (0.98), fertility (0.41) and total embryonic mortality (0.30). Also, between eggshell thickness and each of albumen weight
(0.59) and albumen height (0.81) and between albumen weight with albumen height (0.91). While, direct genetic correlation demonstrates highly negative correlation between egg shape index with yolk weight (-0.98). Furthermore, it can be observed from data of maternal genetic correlations that there are highly positive genetic correlations between hatching egg weight and each of egg shape index (0.94), eggshell thickness (0.91), albumen weight (0.99), albumen height (0.74), yolk weight (0.37) fertility (0.60), total embryonic mortality $(0.64)$ and hatchability of fertile eggs (0.50). Moreover, between egg shape index and each of eggshell thickness (0.98), albumen height $(0.63)$, fertility $(0.50)$ and total embryonic mortality (0.97). Also, between eggshell thickness and each of albumen weight (0.97) and albumen height (0.98) and total embryonic mortality (0.50). Also, maternal genetic correlation demonstrates highly negative correlation between egg shape index with albumen weight $(-0.99)$ and yolk weight (-0.98). Moreover, between yolk weight and each of eggshell thickness (-0.37), albumen weight ($0.96)$ and albumen height (-0.98).

Data of Table 5 demonstrate phenotypic correlations between some performance traits of Gimmizah chickens selected for body weight at 12- wk of age. It can be observed that there are highly positive significant phenotypic correlations between fertility with hatching egg weight (0.45), eggshell thickness (0.87), albumen weight (0.42) and albumen height (0.40). Also, between yolk weight with egg shape index (0.33), and between albumen height with 
hatching egg weight (0.87), egg shape index (0.47), eggshell thickness (0.42), and albumen weight (0.87). Moreover, between albumen weight with each of hatching egg weight (0.94), egg shape index (0.49), and eggshell thickness (0.44). and between eggshell thickness with hatching egg weight (0.40). Besides, between egg shape index with hatching egg weight (0.44). Moreover, there are highly negative significant phenotypic correlations between fertility with egg shape index (-0.35) and between yolk weight with hatching egg weight $(-0.31)$, eggshell thickness (-0.69), albumen weight (-0.37) and albumen height (-0.42). Also, between eggshell thickness with egg shape index (-0.28).

Generally, our results indicate that most egg quality traits are influenced by direct and maternal effects after body weight selection. Also, it can be concluded from the reported results that egg weight is highly genetical correlated in both direct and maternal influence with egg shape index, eggshell thickness, albumen weight and albumen height.

In accordance with our results, Emamgholi Begli et al. (2010) and Okonkwo (2014) showed positive genetic correlation of egg weight with eggshell thickness and positive correlation was found between shape index with shell thickness (0.55). Moreover, Kheirkhah et al. (2017) found high positive correlation between egg weight with albumen weight. Discrepancies were found in the literature concerning the genetic and phenotypic correlations between egg quality and reproductive traits especially after selection. Hartman et al. (2003) found strong positive genetic correlation between yolk weight and albumen weight. The correlation estimates between different reproduction traits are in agreement with the report of Padhi and Chatterjee (2013) who mentioned that correlation estimates between different reproduction traits indicates that the improvement in these traits will improve the other traits as correlated response. Also, Zhang et al. (2005) found that genetic correlations between albumen height and albumen weight (0.34), and between albumen weight and yolk weight $(0.65)$ were positive. Also, the phenotypic correlation between egg weight and eggshell thickness was low and the genetic correlates were moderate. While Olawumi and Ogunlade (2008) found that there were no significant correlations between the shape index and internal quality traits with the exception of albumen weight and yolk weight. The significant positive genetic and phenotypic correlations between most of the egg quality traits and hatchability had been confirmed by several authors (Bennet, 1992 and Barnett et al., 2004). Moreover, Kul and Seker (2004) reported significant positive correlations between the albumen index and albumen height, albumen weight. Therefore, the knowledge of genetic and phenotypic correlations among the studied traits of egg quality and hatchability after body weight selection is essential for any genetic improvement program.

It could be noticed that there are significant positive genetic correlation between most of the studied egg quality traits and hatchability.

\section{CONCLUSION}

Generally, our results indicate that most egg quality traits are influenced by direct and maternal effects due to body weight selection. Also, the knowledge of genetic and phenotypic 


\section{Genetic; Hatchability; Egg Quality; Heritability}

correlations among the studied traits of egg quality and hatchability after body weight selection is essential for any genetic improvement program.

The obtained results of low estimates of heritability for fertility and hatchability and the highly estimates for egg quality traits besides the highly direct and maternal genetic correlations suggesting the applicability of some egg quality traits in programming the selection index combining with body weight selection as indirect way for improving fertility and hatchability with body weight.

Table (1): Effect of body weight selection at 12- week of age on some performance traits of Gimmizah chickens $(\overline{\times} \pm S E)$

\begin{tabular}{|c|c|c|c|}
\hline Traits & $\begin{array}{c}\text { Base population } \\
\left(\mathbf{G}_{\mathbf{0}}\right)\end{array}$ & $\begin{array}{c}1^{\text {st }} \text { generation } \\
\left(G_{1}\right)\end{array}$ & $\begin{array}{c}2^{\text {nd }} \text { generation } \\
\left(G_{2}\right)\end{array}$ \\
\hline Hen's body weight at $45-$ wk of age ( $\mathrm{g}$ ) & $1823.43^{\mathrm{B}} \pm 7.16$ & $1975.5^{\mathrm{A}} \pm 37.58$ & $2017.06^{\mathrm{A}} \pm 15.22$ \\
\hline Hatching egg weight $(\mathrm{g})$ & $52.34^{\mathrm{B}} \pm 0.03$ & $52.53^{\mathrm{B}} \pm 0.47$ & $53.24^{\mathrm{A}} \pm 0.21$ \\
\hline Egg shape index & $75.04^{\mathrm{C}} \pm 0.05$ & $76.08^{\mathrm{B}} \pm 0.27$ & $77.23^{\mathrm{A}} \pm 0.16$ \\
\hline Egg surface area $\quad\left(\mathrm{cm}^{2}\right)$ & $66.73^{C} \pm 0.01$ & $71.54^{\mathrm{B}} \pm 0.39$ & $73.26^{\mathrm{A}} \pm 0.22$ \\
\hline Eggshell density $\left(\mathrm{g} / \mathrm{cm}^{2}\right)$ & $6.93^{B} \pm 0.02$ & $6.77^{B} \pm 0.09$ & $7.36^{\mathrm{A}} \pm 0.14$ \\
\hline Eggshell thickness without membranes (mm) & $0.34^{\mathrm{B}} \pm 0.05$ & $0.33^{\mathrm{C}} \pm 0.38$ & $0.39^{\mathrm{A}} \pm 0.59$ \\
\hline Eggshell weight $\quad(\mathrm{g})$ & $4.63^{\mathrm{B}} \pm 001$ & $4.67^{\mathrm{B}} \pm 0.07$ & $5.61^{\mathrm{A}} \pm 0.10$ \\
\hline Albumen weight & $30.98^{\mathrm{B}} \pm 0.03$ & $30.74^{\mathrm{B}} \pm 0.36$ & $31.73^{\mathrm{A}} \pm 0.19$ \\
\hline Albumen height $(\mathrm{mm})$ & $7.64^{B} \pm 0.03$ & $7.55^{\mathrm{B}} \pm 0.23$ & $8.51^{\mathrm{A}} \pm 0.40$ \\
\hline Yolk weight & $16.73^{C} \pm 0.01$ & $17.11^{\mathrm{B}} \pm 0.14$ & $17.43^{\mathrm{A}} \pm 0.16$ \\
\hline Yolk weight & $32.00^{\mathrm{A}} \pm 001$ & $32.66^{\mathrm{A}} \pm 0.25$ & $30.94^{\mathrm{B}} \pm 0.23$ \\
\hline Albumen weight & $59.17^{\mathrm{B}} \pm 0.02$ & $58.39^{\mathrm{C}} \pm 0.28$ & $62.97^{\mathrm{A}} \pm 0.28$ \\
\hline Eggshell weight & $8.83^{\mathrm{B}} \pm 0.01$ & $8.88^{\mathrm{B}} \pm 0.09$ & $10.79^{\mathrm{A}} \pm 0.20$ \\
\hline Yolk / albumen ratio & $54.13^{C} \pm 0.07$ & $56.28^{\mathrm{A}} \pm 0.69$ & $55.30^{\mathrm{B}} \pm 0.59$ \\
\hline Fertility $\%$ & $84.74^{\mathrm{B}} \pm 0.79$ & $92.52^{\mathrm{A}} \pm 2.55$ & $93.75^{\mathrm{A}} \pm 1.42$ \\
\hline Total embryonic mortality $\%$ & $18.88^{\mathrm{A}} \pm 0.95$ & $13.59^{\mathrm{B}} \pm 3.43$ & $13.12^{\mathrm{B}} \pm 2.13$ \\
\hline Hatchability of fertile eggs $\%$ & $80.62^{\mathrm{B}} \pm 0.94$ & $80.95^{\mathrm{B}} \pm 3.85$ & $85.87^{\mathrm{A}} \pm 2.12$ \\
\hline Hatched chick body weight for hens & $42.29^{\mathrm{B}} \pm 0.07$ & $42.59^{\mathrm{B}} \pm 0.05$ & $44.69^{\mathrm{A}} \pm 0.24$ \\
\hline Hatched chick weight for hens $\%$ & $80.85^{\mathrm{B}} \pm 0.20$ & $81.31^{\mathrm{B}} \pm 0.93$ & $83.89^{\mathrm{A}} \pm 0.45$ \\
\hline
\end{tabular}

$\mathrm{A}, \mathrm{b}$ and $\mathrm{c}$ means in the same row within generations with different letters, differ significantly $(\mathrm{p}<0.05)$ 
Table (2): Estimates of additive genetic variance $\left(\sigma^{2}\right)$ and standard error (SE) for some performance traits of Gimmizah chickens selected for body weight at 12-wk of age

\begin{tabular}{|c|c|c|c|}
\hline TRAITS & $\sigma_{\mathrm{a}}^{2} \pm \mathrm{SE}$ & $\sigma_{m}^{2} \pm \mathrm{SE}$ & $\sigma_{p e}^{2} \pm \mathrm{SE}$ \\
\hline Hen's body weight at 45- wk of age & $1.01 \pm 0.24$ & $1.02 \pm 0.29$ & $1.04 \pm 0.41$ \\
\hline Hatching egg weight & $1.58 \pm 0.79$ & $1.97 \pm 0.31$ & $2.26 \pm 0.72$ \\
\hline Egg shape index & $1.51 \pm 0.51$ & $20.5 \pm 1.13$ & $19.04 \pm 3.13$ \\
\hline Egg surface area & $1.08 \pm 0.17$ & $0.32 \pm 0.03$ & $2.37 \pm 0.75$ \\
\hline Eggshell density & $1.06 \pm 0.22$ & $46.29 \pm 0.52$ & $0.57 \pm 0.09$ \\
\hline Eggshell thickness without membranes & $1.68 \pm 0.32$ & $2.30 \pm 0.67$ & $7.87 \pm 1.73$ \\
\hline Albumen Weight & $1.81 \pm 0.12$ & $0.69 \pm 0.14$ & $1.85 \pm 1.19$ \\
\hline Albumen height & $1.05 \pm 0.19$ & $1.12 \pm 0.33$ & $0.70 \pm 0.11$ \\
\hline Yolk weight & $1.89 \pm 0.05$ & $94.5 \pm 4.12$ & $1.95 \pm 0.23$ \\
\hline Yolk weight ratio & $1.72 \pm 0.13$ & $1.98 \pm 0.40$ & $0.77 \pm 0.03$ \\
\hline Eggshell weight & $1.04 \pm 0.29$ & $0.94 \pm 0.46$ & $0.27 \pm 0.11$ \\
\hline Eggshell weight \% & $0.07 \pm 0.15$ & $36.42 \pm 1.25$ & $0.31 \pm 0.02$ \\
\hline Albumen weight $\%$ & $1.08 \pm 0.23$ & $2.61 \pm 0.92$ & $3.26 \pm 0.92$ \\
\hline Yolk / albumen & $1.08 \pm 0.26$ & $2.39 \pm 1.39$ & $2.30 \pm 0.91$ \\
\hline Fertility & $1.35 \pm 0.50$ & $1.49 \pm 0.23$ & $1.63 \pm 0.14$ \\
\hline Total embryonic mortality $\%$ & $1.06 \pm 0.11$ & $1.04 \pm 0.13$ & $1.06 \pm 0.11$ \\
\hline Hatchability of fertile eggs $\%$ & $1.08 \pm 0.11$ & $1.04 \pm 0.16$ & $1.06 \pm 0.11$ \\
\hline Hatched chick body weight for hens & $1.35 \pm 0.50$ & $2.60 \pm 0.48$ & $3.21 \pm 0.18$ \\
\hline Hatched chick body weight for hens percent & $1.08 \pm 0.19$ & $1.04 \pm 0.32$ & $1.15 \pm 0.40$ \\
\hline
\end{tabular}
$\sigma_{\mathrm{a}}^{2}$ : direct additive genetic effect $\sigma_{\mathrm{m}}^{2}$ : maternal additive genetic effect $\sigma_{\text {pe }}^{2}$ : permanent environmental hen effects 
Table (3): Heritability estimates $\left(\mathrm{h}^{2}\right)$ and standard errors (SE) of some performance traits for Gimmizah chicken selected for body weight at 12-wk of age

\begin{tabular}{|c|c|c|c|}
\hline TRAITS & $\mathbf{h}_{\mathrm{a}}^{2} \pm \mathrm{SE}$ & $h_{m}^{2} \pm S E$ & $\mathrm{~h}_{\text {pe }}^{2} \pm \mathrm{SE}$ \\
\hline Hen's body weight at $45-$ wk of age & $0.50 \pm 0.01$ & $0.25 \pm 0.01$ & $0.25 \pm 0.01$ \\
\hline Hatching egg weight & $0.54 \pm 0.10$ & $0.29 \pm 0.05$ & $0.34 \pm 0.05$ \\
\hline Egg shape index & $0.52 \pm 0.01$ & $0.84 \pm 0.01$ & $0.94 \pm 0.06$ \\
\hline Egg surface area & $0.50 \pm 0.01$ & $0.12 \pm F$ & $0.39 \pm F$ \\
\hline Eggshell density & $0.84 \pm 0.08$ & $0.80 \pm 0.03$ & $0.03 \pm 0.01$ \\
\hline Eggshell thickness without membranes & $0.72 \pm 0.01$ & $0.31 \pm \mathrm{F}$ & $0.40 \pm 0.05$ \\
\hline Albumen weight & $0.56 \pm 0.02$ & $0.13 \pm 0.01$ & $0.44 \pm 0.08$ \\
\hline Albumen height & $0.51 \pm 0.07$ & $0.40 \pm 0.08$ & $0.20 \pm 0.05$ \\
\hline Yolk weight & $0.73 \pm 0.02$ & $0.72 \pm 0.04$ & $0.03 \pm 0.01$ \\
\hline Yolk weight ratio & $0.54 \pm 0.02$ & $0.35 \pm 0.04$ & $0.11 \pm 0.01$ \\
\hline Eggshell weight & $0.63 \pm 0.13$ & $0.17 \pm 0.06$ & $0.43 \pm 0.16$ \\
\hline Shell weight \% & $0.63 \pm 0.06$ & $0.56 \pm 0.02$ & $0.19 \pm 0.02$ \\
\hline Albumen weight $\%$ & $0.50 \pm 0.01$ & $0.11 \pm F$ & $0.44 \pm F$ \\
\hline Yolk / albumen ratio & $0.50 \pm 0.01$ & $0.19 \pm 0.03$ & $0.34 \pm 0.02$ \\
\hline Fertility & $0.22 \pm 0.01$ & $0.20 \pm 0.05$ & $0.19 \pm 0.04$ \\
\hline Total embryonic mortality & $0.20 \pm 0.01$ & $0.25 \pm 0.04$ & $0.25 \pm 0.04$ \\
\hline Hatchability of fertile eggs & $0.20 \pm 0.01$ & $0.25 \pm 0.04$ & $0.25 \pm 0.03$ \\
\hline Hatched chick body weight for hens & $0.50 \pm 0.01$ & $0.65 \pm 0.05$ & $0.27 \pm 0.05$ \\
\hline Hatched chick body weight for hens percent & $0.50 \pm 0.01$ & $0.24 \pm 0.06$ & $0.26 \pm 0.09$ \\
\hline
\end{tabular}

$\mathrm{h}_{\mathrm{a}}^{2}$ : direct heritability genetic effect

$\mathrm{h}^{2} \mathrm{~m}$ : maternal heritability genetic effect

$\mathrm{h}_{\text {pe }}^{2}$ : permanent environmental hen effects

F : Non - estimable 
Table (4): Direct (above diagonal) and maternal(below diagonal) genetic correlations ( \pm standard error) of some performance traits for Gimmizah chickens selected for body weight

\begin{tabular}{|c|c|c|c|c|c|c|c|c|c|c|c|c|}
\hline & $\begin{array}{l}\text { Body } \\
\text { weight at } \\
45-\text { wk of } \\
\text { age }\end{array}$ & $\begin{array}{l}\text { Hatching } \\
\text { egg weigh }\end{array}$ & $\begin{array}{l}\text { Egg shape } \\
\text { index }\end{array}$ & \begin{tabular}{|l} 
Eggshell \\
thickness
\end{tabular} & $\begin{array}{l}\text { Albumen } \\
\text { Weight }\end{array}$ & $\begin{array}{l}\text { Albumen } \\
\text { height }\end{array}$ & $\begin{array}{l}\text { Yolk } \\
\text { weight }\end{array}$ & Fertility & $\begin{array}{l}\text { Total } \\
\text { embryoni } \\
\text { mortality }\end{array}$ & $\begin{array}{l}\text { Hatchability } \\
\text { of fertile egg }\end{array}$ & $\begin{array}{l}\text { Hatched } \\
\text { chick bod } \\
\text { weight }\end{array}$ & \\
\hline $\begin{array}{l}\text { Body weight at } \\
45 \text { - wk of age }\end{array}$ & & $0.10 \pm 0.01$ & $0.10 \pm 0.01$ & $0.10 \pm 0.01$ & $0.10 \pm 0.02$ & $0.10 \pm 0.01$ & $0.01 \pm 0.01$ & $0.10 \pm 0.01$ & $0.10 \pm 0.01$ & $0.10 \pm 0.01$ & $0.10 \pm 0.01$ & $\begin{array}{l}\text { Body weight at } \\
45 \text { - wk of age }\end{array}$ \\
\hline $\begin{array}{l}\text { Hatching egg } \\
\text { weight }\end{array}$ & $0.10 \pm 0.0$ & & $0.74 \pm 0.0$ & $0.54 \pm 0.10$ & $0.90 \pm 0.02$ & $0.68 \pm 0.0$ & $-0.06 \pm 0.04$ & $0.55 \pm 0.02$ & $0.40 \pm 0.02$ & $0.50 \pm 0.01$ & $0.11 \pm 0.02$ & $\begin{array}{l}\text { Hatching egg } \\
\text { weigh }\end{array}$ \\
\hline Egg shape index & $0.10 \pm 0.01$ & $0.94 \pm 0.04$ & & $0.99 \pm 0.16$ & $0.78 \pm 0.07$ & $0.98 \pm 0.03$ & $-0.98 \pm 0.05$ & $0.41 \pm 0.01$ & $0.30 \pm 0.01$ & $0.25 \pm 0.01$ & $0.11 \pm 0.03$ & Egg shape index \\
\hline Albumen height & $0.10 \pm 0.02$ & $0.74 \pm 0.25$ & $0.63 \pm 0.32$ & $0.98 \pm 0.08$ & $-0.27 \pm 0.24$ & & $0.42 \pm 0.15$ & $0.09 \pm 0.02$ & $0.10 \pm 0.02$ & $0.10 \pm 0.02$ & $0.33 \pm 0.15$ & Albumen height \\
\hline Yolk weight & $0.10 \pm 0.01$ & $0.37 \pm 0.09$ & $-0.98 \pm 0.0 \$$ & $-0.37 \pm 0.20$ & $-0.96 \pm 0.06$ & $-0.98 \pm 0.0$ & & $0.10 \pm 0.02$ & $0.10 \pm 0.02$ & $0.10 \pm 0.04$ & $0.12 \pm 0.05$ & Yolk weight \\
\hline Fertility & $0.10 \pm 0.01$ & $0.60 \pm 0.01$ & $0.50 \pm 0.03$ & $0.09 \pm 0.05$ & $0.10 \pm 0.04$ & $0.08 \pm 0.06$ & $0.10 \pm 0.05$ & & $0.10 \pm 0.03$ & $0.10 \pm 0.01$ & $0.10 \pm 0.02$ & Fertility \\
\hline $\begin{array}{l}\text { Total embryonic } \\
\text { mortality }\end{array}$ & $0.10 \pm 0.01$ & $0.64 \pm 0.29$ & $0.97 \pm 0.28$ & $0.50 \pm \mathrm{F}$ & $0.45 \pm 0.30$ & $0.01 \pm F$ & $0.10 \pm 0.05$ & $0.10 \pm 0.03$ & & $0.09 \pm 0.07$ & $0.10 \pm 0.04$ & $\begin{array}{l}\text { Total } \\
\text { embryonic }\end{array}$ \\
\hline
\end{tabular}


Table (5): Phenotypic correlations between some performance traits of Gimmizah chickens selected for body weight

\begin{tabular}{|c|c|c|c|c|c|c|c|c|c|c|}
\hline & $\begin{array}{l}\text { Body } \\
\text { weight } \\
\text { at } 45- \\
\text { wk of ag }\end{array}$ & $\begin{array}{l}\text { Hatching } \\
\text { egg weight }\end{array}$ & $\begin{array}{l}\text { Egg } \\
\text { shape } \\
\text { index }\end{array}$ & $\begin{array}{l}\text { Egg shell } \\
\text { thickness }\end{array}$ & $\begin{array}{l}\text { Albumen } \\
\text { Weight }\end{array}$ & $\begin{array}{l}\text { Albumen } \\
\text { height }\end{array}$ & $\begin{array}{l}\text { Yolk } \\
\text { weight }\end{array}$ & Fertility & $\begin{array}{l}\text { Total } \\
\text { embryonic } \\
\text { mortality }\end{array}$ & $\begin{array}{l}\text { Hatchability } \\
\text { of fertile } \\
\text { eggs }\end{array}$ \\
\hline Hatching egg weight & $0.0676^{*}$ & & & & & & & & & \\
\hline Egg shape index & $0.0703 *$ & $0.4413 * * *$ & & & & & & & & \\
\hline Egg shell thickness & $0.0557 *$ & $0.4071 * * *$ & $-0.2808 * * *$ & & & & & & & \\
\hline Albumen Weight & $0.0385^{*}$ & $0.9481 * * *$ & $0.4975^{* * *}$ & $0.4450 * * *$ & & & & & & \\
\hline Albumen height & -0.0015 & $0.8794 * * *$ & $0.4770 * * *$ & $0.4207 * * *$ & $0.8794 * * *$ & & & & & \\
\hline Yolk weight & 0.0344 & $-0.3129 * * *$ & $0.3339 * * *$ & $-0.6936 * * *$ & $-0.3738 * *$ & $-0.4241 * * *$ & & & & \\
\hline Fertility & 0.0083 & $0.4573 * * *$ & $-0.3593 * * *$ & $0.8793 * * *$ & $0.4224 * * *$ & $0.4068 * * *$ & $-0.4561 * * *$ & & & \\
\hline $\begin{array}{l}\text { Total } \\
\text { embrvonic mortality }\end{array}$ & 0.0286 & -0.0212 & -0.0114 & -0.0722 & $-0.0475^{*}$ & $-0.0419 *$ & 0.0348 & 0.0254 & & \\
\hline Hatchability of & -0.0336 & 0.0164 & 0.0027 & $0.0685^{* *}$ & 0.0149 & 0.0362 & -0.0360 & -0.0001 & -0.0328 & \\
\hline $\begin{array}{l}\text { Hatched chick } \\
\text { body weight }\end{array}$ & $0.0615^{*}$ & $0.0799 *$ & 0.0201 & $0.0561 *$ & 0.0312 & -0.0083 & 0.0234 & -0.0012 & -0.0328 & 0.0269 \\
\hline
\end{tabular}

$*$ Significant at level $0.05 \quad * *$ Significant at level $0.01 \quad * * *$ Significant at level 0.001 


\section{REFERENCES}

Ajayi, F. O. 2010. Nigerian indigenous chicken: a valuable genetic resource for meat and egg production. Asian J. Poult. Sci. 4:164-172.

Amira, M.; Nowier, S. I.; Ramadan, M.Y.; Mahrous, Belgasim, S.S.H. and EL-Denary, M. E., 2018. Genetic and productive studies on egyptian local and exotic laying hen breeds. Egypt. Poult. Sci., 38: 179-194.

Ashour, A. F.; Badwi, Y. K. and Ragaa, E.A. 2015. Effect of selection for body weight on egg production, egg quality, fertility and hatchability traits in Elsalam chicken strain in egypt. J. Animand Poult. Prod., Ma. Univ. 6: 781- 796 .

Ayman, E.T.; Fawzy.A. and Abd,E.G. 2013. Improving production traits for El-Salam and Mandarah chicken strains by crossing ii-estimation of crossbreeding effects on egg production and egg quality traits. International Journal of Nutrition and Food Engineering. 10: 982-987.

Barbieri, A.; Ono, R.K.; Cursino, L.L.; Farah, M.M.; Pires, M.P.; Bertipaglia, T.S.; Pires, A.V. ; Cavani, L.; Carreno, L.O.; and Fonseca, R. 2015. Fonseca genetic parameters for body weight in meat quail. Poult. Sci. 94:169-171.

Barnett, D.M.; Kumpula, B.L.; Petryk, R.L.; Robinson, N.A.; Renema, R.A. and Robinson, F.E. 2004. Hatchability and early chick growth potential of broiler breeder eggs with hairline cracks. Journal of App Poult. Res. 13: 65-70.

Bennet, A.F.; Lewski, R.E.; Mittler, J.E. 1992. Evolutionary adaptation to temperature. I. Fitness responses of Escherichia coli to changes in its thermal environment. Evolution. 46:16-30.

Bennet, C.D. 1992. The influence of shell thickness on hatchability in commercial broiler breeder flocks. App. Poult. Res. 1:61-65.

Bennewitz, J.; Morgades, O.; Preisinger, R.; Thaller, G. and Kalm, E. 2007. Variance component and breeding value estimation for reproductive traits in laying hens using a Bayesian threshold model. Poult. Sci. 86:823-828 .

Carter, T. C. 1975. The hen's egg: relationships of seven characteristics of the strain of hen to the incidence of cracks and other shell defects. Br. Poult. Sci. 16:289-296.

Curtis, P.A.; Gardner, F. A. and Mellor. D. B. 1985. Acomparison of selected quality and compositional characteristics of brown and white shell eggs. I. Shell quality. Poult. Sci. 64:297-301.

Emamgholi Begli, H.; Zerehdaran, S.; Hassani, S.; Abbasi, M.A. and Khan Ahmadi, A.R. 2010. Heritability, genetic and phenotypic correlations of egg quality traits in Iranian native fowl. Brit. Poult. Sci. 51: 740- 744 .

Ghorbani, S. h.; Kamali, M. A.; Abbasi, M. A. and Ghafouri.K. F. 2012. Estimation of maternal effects on some economic traits of north Iranian native fowls using different models. J. Agr. Sci. 14: 95-103.

Grosso, J.; Balieiro, Eler, J.; Ferraz, J.; Mattos. E. and Michelan,T. 2010. Comparison of different models to estimate genetic parameters for carcass traits in a commercial broiler line. Genet. Mol. Res. 9:908-918 .

Hartmann, C.; Johansson, K.; Strandberg, E. and Rydhmer, L. 2003. Genetic correlations between the 
Genetic; Hatchability; Egg Quality; Heritability

maternal genetic effect on chick weight and the direct genetic effects on egg composition traits in a White Leghorn line. Poult. Sci. 82:1-8.

Hartmann, C.; Strandberg, E.; Rydhmer, L. and Johansson, $\mathbf{K}$. 2002. Genetic relations between reproduction,chick weight and maternal egg composition in a white leghorn line. Acta Agriculturae Scandinavica, Sect. A, Animal Sci. 52: 91-101.

Iraqi, M. M.; Hanafi, M.S.; Khalil, M.H.; EL-Labban, A.M. and ELSisy, M. 2002. Genetic evaluation of growth traits in across breeding experiment involving two local strains of chickens using multi-trait animal model. Livestock research for rural development. 14:69-79.

Kheirkhah, Z.; Hassani, S.; Zerehdaran, S.; Ahani Azari, M.; Sekhavati, M. H. and Salehinasab, M. 2017. Genetic analyses of egg quality in Khorasan razavi native fowl using the bayesian method. Poult. Sci. $.5: 113-121$.

Kul, S. and Seker, I. 2004. Phenotypic correlations between some external and internal egg quality traits in the Japanese quail (Coturnix coturnix japonica). International Journal of Poult. Science. 3: 400-405.

Larivière, J.M.; Michaux, C. and Leroy, P. 2009. Genetic parameters of embryonic viability traits in a traditional chicken breed. Int J Poult. Sci. 8:1183-1188 .

Liu, W; Li, D; Liu, J; Chen, S; Qu, L; Zheng, J; Xu, G. and Yang, N. 2011. A genome-wide SNP scan reveals novel loci for egg production and quality traits in White Leghorn and brown egg dwarf layer s. PLoS One, 6:
$1-8$.

DOI:

10.1371/journal.pone.0028600

Marks, H.L. 1979. Changes in unselected traits accompanying longterm selection for four-week body weight in Japanese quail. Poult. Sci. 58: 269-274.

Meyer, K. 2007.WOMBAT: a tool for mixed model analyses in quantitative genetics by restricted maximum likelihood (REML). J. Zhejiang Univ. Sci. B 8:815-821.

Meyer,K.2010.'wombat:faqs'.WickedW OMBAT.04:41GMT .

Minvielle, F. and Oguz, Y. 2002. Effects of genetics and breeding on egg quality of Japanese quail. Worlds Poult. Sci. J. 58: 291-295 .

Norris, D.and Ngambi, J.W. 2006. Genetic parameter estimates for body weight in local Venda chickens. Tropical Animal Health and Production. 38:605-609 .

Okonkwo, J.C. 2014. Genetic correlation between egg quality traits. Sci.J. Biological Sci. 3:69-72.

Olawumi, S.O. and Ogunlade, J.T.2008. Phenotypic correlation between some external and internal egg quality traits in the exotic ISA brown layer breeders, Asian Journal of Poult. Sci. 2: 30-35.

Padhi, M.K. and Chatterjee, R.N. 2013. Carcass quality traits in four different crossbreds developed for backyard poultry and the effect of age on carcass quality under intensive system of rearing. Ind. J. Anim. Sci. 83:11021108.

Pradeepta, K.R.; Prasanna, K.M.; Bandi, K.M. and Nrusingha, C.B. 2015. Evaluation of different age quality traits and interpretation of their mode of inheritance in white leghorns. Vet. World. 8: 449-452. 
Rahman, M. M.; Islam, M. M. and Mohanta, U. K. 2010. Improvement of Hilly chicken in Bangladesh. Paper presented in annual research review workshop and technology show, BLRI, Savar, Dhaka, Bangladesh, 2223 June.

Saatci, M.; Omed, H. and Ap Dewi, I. 2006. Genetic parameters from univariate and bivariate analyses of egg and weight traits in Japanese quail. Poult. Sci. 85:185-190.

Saleh, K.; Younis, H.H.; Rizkalla, H.E. and Ragaa Abd El-Krim, E. 2008. Direct and correlated response of selection for improving body weight in El-Salam chickens. Egypt. Poult. Sci. 28: 431-454.

Salehinasab, M.; Zerehdaran,S.; Abbasi,M.A.; Alijani,S. and Hassani, S. 2014. Genetic properties of productive traits in Iranian native fowl: genetic relationship between performance and egg quality traits. J. Agr. Sci. Tech., 16: 1055-1062.

Sapp, R.L.; Rekaya, R.; Misztal, I. and Wing, T. 2004.Male and female fertility and hatchability in chickens: A longitudinal mixed model approach. Poult. Sci. 83:1253-1259 .

Saroj, S.; Mana, R.K.; Naba, R.D.; Neena, A.G. and Nirajan, B. 2020. Evaluation of external and internal egg quality traits of indigenous sakini chicken in different generations of selection. Int. Journal.Agriculture and Forestry. 10: 41-48

SAS. 2016. SAS/STAT users guide. SAS Institute INC, Cary, nc27513, USA.

Schmidt, G.S.; Coutinho, L.L.; Figueiredo, E.A.P.; de Ledur, MC. and Alves, H.J. 2003 Morphological genetic markers for selection of broiler lines. Braz. J. Poult. Sci. 5: 175 -178.
Siegel, P. B. and Dunnington, E. A. 1985. Reproductive complications associated with selection for broiler growth. Br. Poult. Sci. 26: 59-72.

Sreenivas, D.; Prakash, G. M.; Mahender, M. and Chatterjee, R.N. 2013. Genetic analysis of egg quality traits in White Leghorn chicken. Vet. World. 6: 263-266.

Stino, F.K.R.; Goher, N.E.; Kamer G.A.R. and Hanash, N.A. 1982. The effect of breed and housing system on the egg quality of white baladi and fayoumi hens in the subtropics. Egypt J. Anim. Prod. 23: 191-198.

Tongsiri, S.; Gilbert, M.; Jeyaruban,G.M.; Hermesch,S.; Julius,H.J.v.; der W.; Li Li. and Chormai,T. 2019. Genetic parameters and inbreeding effects for production traits of the native chickens. AsianAustralas J Anim Sci. 32: 930-938.

Willham, R.L. 1972. The role of maternal effects in animal breeding: III - Biometrical aspects of maternal effects in animals. J. Anim. Sci. 35:1288-1293.

Willham, R.L. 1980. Problems in estimating maternal effects. Livest Prod. Sci. 7: 405-418.

Wolc, A. and Olori, V. E. 2009. Genetics of hatchability Egg quality from the perspective of a chick. Proc. 6th Eur. Poult. Genet. Symp, Będlewo, Poland.

Wolc, A.; Arango, J.; Settar, P.; O'Sullivan, N. P.; Olori, V. E.; White, I. M. S.; Hill, W. G. and Dekkers, J. C. M. 2012. Genetic parameters of egg defects and egg quality in layer chickens. Poult. Sci. 91: 1292- 1298.

Wolc, A.; White, I.M.; Hill, W.G. and Olori, V.E. 2010. Inheritance of hatchability in broiler chickens and its 


\section{Genetic; Hatchability; Egg Quality; Heritability}

relationship to egg quality traits. Poult. Sci .89:2334-40 .

Yavarifard, R.; Ghavi Hossein-Zadeh, N. and Shadparvar, A. A. 2015. Estimation of genetic parameters for reproductive traits in Mehraban sheep. Czech J. Anim. Sci. 60: 281-288.

Yeasmin, T. and Howlider, M.A.R. 1998. Comparative physical features, egg production and egg quality characteristics of normal and dwarf indigenous (Deshi) hens of Bangladesh. J. Appl. Anim. Res. 13:1-
Younis, H.H; Abd El-Ghany, F.A. and Nasra B. Awadein. 2014. Genetic improvement of egg production traits in Dokki-4 strain. 1- Correlated responses, heritability, genetic and phenotypic correlations for egg production and egg quality traits. Egypt. Poult. Sci. 34: 345-362.

Zhang, C.H. 2005. Estimation of sums of random variables: Examples and information bounds. Ann. Stat. 33: 2022-2041. 2 .

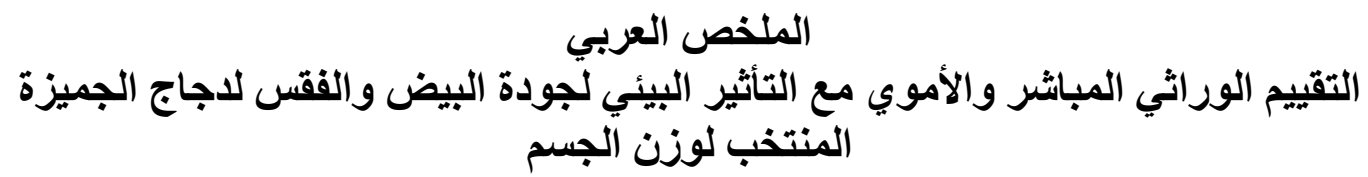

$$
\text { معهد بحوث الإنتاجي الحبواني- مرك، رعز البحوث ادوارد رزق الزربة ـ مصر }
$$

أجريت هذه الدراسة على دجاج الجميزة المنتخب لوزن الجسم عند عمر بات أسبوع خلال ثلاثة مواسم متتالية.

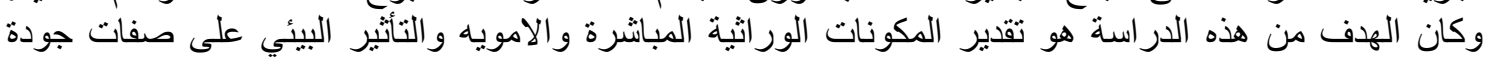

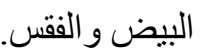

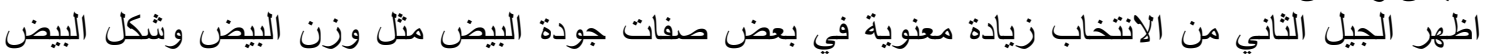

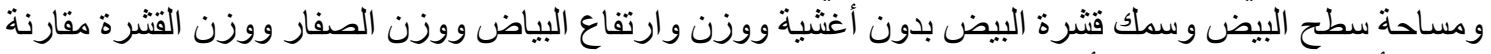

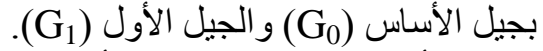
وتفوق تأثثير العوامل المضيفة الأمية على كل من العو امل الخطية والبيئية في كل من وزن بيض التفريخ وشكل

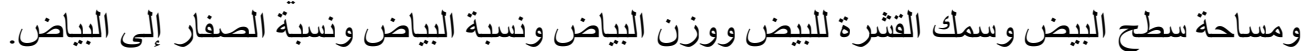

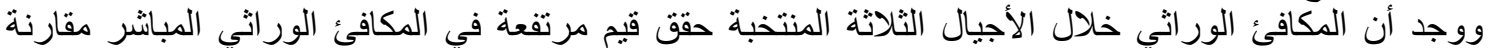

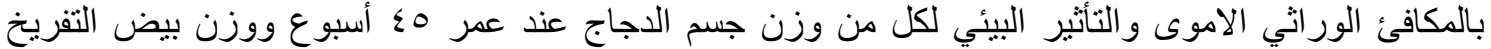

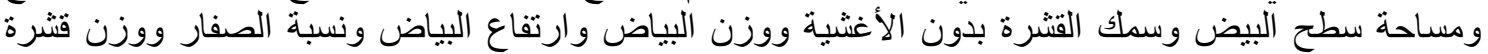

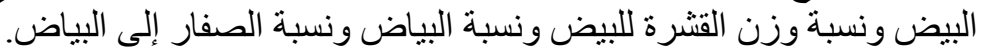

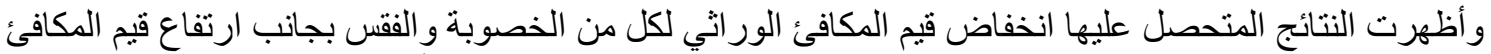

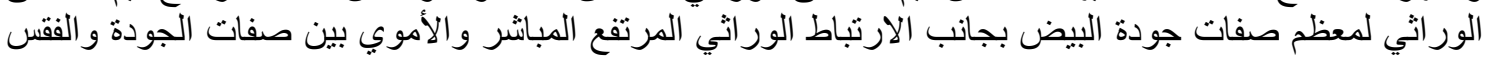

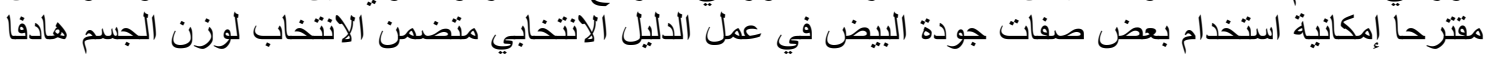
تحسين الخصوبة و الفقس بطريقة غير مباشرة. 